\title{
SPOŁECZNO-EKONOMICZNE UWARUNKOWANIA ROLNICTWA DLA PRODUKCJI ENERGII ODNAWIALNEJ Z BIOMASY ROLNICZEJ W POLSCE
}

\section{SOCIO-ECONOMIC DETERMINANTS OF AGRICULTURE FOR RENEWABLE ENERGY PRODUCTION USING AGRICULTURAL BIOMASS IN POLAND}

\author{
Dorota JANISZEWSKA • Luiza OSSOWSKA \\ Politechnika Koszalińska \\ Wydział Nauk Ekonomicznych \\ ul. E. Kwiatkowskiego 6E, 75-343 Koszalin \\ dorota.janiszewska@tu.koszalin.pl•luiza.ossowska@tu.koszalin.pl
}

\begin{abstract}
Zarys treści: Głównym celem opracowania jest określenie poziomu społeczno-ekonomicznych uwarunkowań dla produkcji energii odnawialnej z biomasy rolniczej w Polsce. Badania poziomu uwarunkowań przeprowadzono w układzie województw (dla obszarów wiejskich) na podstawie informacji z Banku Danych Lokalnych. Poziom uwarunkowań województw wyznaczono metodą wskaźnika syntetycznego. Do analizy przyjęto następujące cechy: udział gospodarstw rolnych z właścicielem do 40 roku życia, rolna siła robocza w AWU na 100 ha użytków rolnych, udział gospodarstw z kierującym posiadającym minimum średnie wykształcenie, udział gospodarstw wielkopowierzchniowych w ogólnej liczbie gospodarstw, zużycie nawozów mineralnych na 1 ha użytków rolnych oraz liczba ciągników przypadająca ha 100 ha użytków rolnych. W wyniku zastosowania cechy syntetycznej podzielono badane województwa na trzy grupy w zależności od poziomu badanych uwarunkowań (poziom wysoki, średni i niski).
\end{abstract}

Słowa kluczowe: uwarunkowania społeczno-ekonomiczne, biomasa rolnicza, rolnictwo, obszary wiejskie.

\section{Wstęp}

Rolnictwo spełnia wiele ważnych funkcji, wśród których J. S. Zegar (2012, s. 71) wymienia pięć podstawowych: żywnościową, produkcji dóbr (surowców) nieżywnościowych, ekonomiczną, społeczną oraz ekologiczną. Obecnie wiele się mówi o wielofunkcyjności rolnictwa, którą można rozpatrywać na różnych poziomach, choć głównie na poziomie gospodarstwa rolnego. W takim znaczeniu wielofunkcyjność zdaniem J. S. Zegara (2012, s. 70) posiada dwa kierunki - poszerzony oraz pogłębiony. Kierunek poszerzony oznacza przede wszystkim rozszerzenie działalności gospodarstw rolnych o nowe obszary (np. agroturystyka, energia odnawialna, handel żywnością), dywersyfikację produkcji (np. biopaliwa, rośliny 
włókniste), zarządzanie przyrodą i krajobrazem (ochrona wód, rzadkich gatunków roślin i zwierząt) oraz tworzenie przedsiębiorstw rolno-przemysłowych. Natomiast kierunek pogłębiony może obejmować takie działania, jak np. produkcja metodami organicznymi czy wytwarzanie żywności, stosując tradycyjne technologie. W takim kontekście wytwarzanie energii odnawialnej z biomasy rolniczej również stwarza możliwość realizacji idei wielofunkcyjności rolnictwa.

Biomasa, zgodnie z definicją zawartą w dyrektywie Rady i Parlamentu Europejskiego (2009, art. 2e), oznacza ulegającą biodegradacji część produktów, odpadów lub pozostałości pochodzenia biologicznego z rolnictwa (łącznie z substancjami roślinnymi oraz zwierzęcymi), leśnictwa i związanych działów przemysłu, w tym rybołówstwa i akwakultury, jak również ulegającą biodegradacji część odpadów przemysłowych i miejskich. Biomasę pochodzenia rolniczego stanowią przede wszystkim jednoroczne i wieloletnie rośliny przeznaczane na cele energetyczne (źródła biomasy ciekłej lub stałej) oraz produkty i pozostałości związane z produkcją roślinną lub hodowlą zwierząt.

Jak słusznie podkreślają J. Kuś i in. (2006, s. 211), wykorzystanie części produkcji rolnej na cele energetyczne może przynieść obszarom wiejskim wiele korzyści. Wśród głównych zalet wymieniają oni m.in.: tworzenie nowych miejsc pracy, gwarancję trwałych (stabilnych) dochodów, która sprzyja procesowi modernizacji i restrukturyzacji rolnictwa, wsparcie inicjatyw lokalnych, dzięki stworzeniu podstaw dla rozwoju przedsiębiorczości. Ponadto wykorzystanie biomasy na cele energetyczne może przynieść korzyści dla całej gospodarki w postaci poprawy stanu środowiska naturalnego (obieg zamknięty $\mathrm{CO}_{2}$, redukcja emisji $\mathrm{NO}_{x}$ ) oraz zwiększenia bezpieczeństwa energetycznego.

\section{Cel i metody}

Głównym celem przyjętym w pracy jest określenie poziomu społeczno-ekonomicznych uwarunkowań rolnictwa dla produkcji energii odnawialnej z biomasy rolniczej w Polsce. Badania poziomu uwarunkowań przeprowadzono w układzie województw na podstawie informacji z Banku Danych Lokalnych oraz opracowań Głównego Urzędu Statystycznego: Charakterystyka gospodarstw rolnych w 2013 roku oraz Rocznik statystyczny rolnictwa 2014. Analizę przeprowadzono dla roku 2013². Dla wyznaczenia poziomu uwarunkowań wykorzystano metodę miernika syntetycznego. Przyjęto następujące cechy proste:

- udział gospodarstw rolnych z właścicielem do 40 roku życia,

- udział gospodarstw z kierującym posiadającym minimum średnie wykształcenie,

- rolna siła robocza w AWU na 100 ha użytków rolnych,

- udział gospodarstw wielkopowierzchniowych w ogólnej liczbie gospodarstw,

- zużycie nawozów mineralnych na 1 ha użytków rolnych,

- liczba ciągników przypadająca na 100 ha użytków rolnych.

Wskaźnik rolna siła robocza w AWU na 100 ha użytków rolnych potraktowano jako destymulantę, natomiast resztę cech jako stymulanty dla produkcji energii odnawialnej z biomasy rolniczej.

Wymienione cechy proste znormalizowano za pomocą procesu unityzacji, wykorzystując następujące formuły (Wysocki i Lira 2003, s. 173-175):

1 Z uwagi na brak danych dla 2013 r. udział gospodarstw rolnych z właścicielem do 40 roku życia oszacowano dla 2010 r. z danych Powszechnego Spisu Rolnego. 
$z_{i j}=\frac{x_{j}-\min _{i}\left\{x_{j}\right\}}{\max _{i}\left\{x_{j}\right\}-\min _{i}\left\{x_{j}\right\}} \quad$ dla stymulant,

$z_{i j}=\frac{\max _{i}\left\{x_{j}\right\}-x_{j}}{\max _{i}\left\{x_{j}\right\}-\min _{i}\left\{x_{j}\right\}} \quad$ dla destymulant.

Wartość wskaźnika syntetycznego wyznaczono, stosując metodę bezwzorcową, która polega na uśrednieniu znormalizowanych wartości przyjętych w analizie cech prostych według następującej formuły:

$q_{i}=\frac{\sum_{j=1}^{m} z_{i j}}{m},(i=1,2, \ldots, n) ;$ wartości cechy syntetycznej $q_{i}$ należą do przedziału $(0,1)$.

Na podstawie wartości wskaźnika syntetycznego, jego średniej arytmetycznej oraz odchylenia standardowego badane województwa podzielono na trzy klasy, które charakteryzują się różnym poziomem uwarunkowań społeczno-ekonomicznych dla produkcji energii odnawialnej z biomasy rolniczej (Parysek i Wojtasiewicz 1979, s. 20):

- klasa I- wysoki poziom - $\mathrm{W}<\left(\mathrm{x}_{\mathrm{sr}}-0,5 \mathrm{~s}_{\mathrm{x}}\right)$

- klasa II-średni poziom - $\left(x_{s r}-0,5 s_{x}\right) £ W €\left(x_{s r}+0,5 s_{x}\right)$

- klasa III - niski poziom $-W>\left(x_{s r}+0,5 s_{x}\right)$

\section{Wyniki badań}

Zdaniem S. Krasowicza oraz M. Matyki (2012, s. 65) Polska dysponuje stosunkowo dużym potencjałem rolnictwa, który jest wyznaczony głównie przez areał użytków rolnych i zasoby ziemi, siłę roboczą oraz kapitał. Jak wynika z badań W. Poczty (2010, s. 9-43), obok warunków przyrodniczych o stopniu wykorzystania istniejącego potencjału, zróżnicowaniu regionalnym, jak również konkurencyjności rolnictwa decydują w znacznej mierze również czynniki ekonomiczno-organizacyjne, w tym także o charakterze makroekonomicznym.

Na obszarach wiejskich Polski występuje wiele problemów, zwłaszcza o charakterze społecznym (demograficznym). Zdaniem W. Poczty (2013, s. 162) szczególną uwagę należy zwrócić na przemiany demograficzne zachodzące wśród ludności rolnej. Jednym z głównych niekorzystnych zjawisk jest proces starzenia się właścicieli gospodarstw rolnych. Młodzi rolnicy (do 40 roku życia) cechują się większą skłonnością do inwestowania we własne gospodarstwo rolne, lepiej dostosowują się do zmieniającego się otoczenia i przyswajają efekty postępu technicznego oraz wykazują większą elastyczność na wprowadzanie innowacji. W związku z tym mogą być również zainteresowani alternatywnymi formami dochodu, takimi jak np. produkcja biomasy na cele energetyczne.

Średnia wartość wskaźnika udziału gospodarstw rolnych z właścicielem do 40 roku życia w Polsce kształtuje się na poziomie 22,8\%. Najwyższe wartości cechują województwa: podlaskie $(26,7 \%)$, kujawsko-pomorskie $(26,2 \%)$, lubelskie $(25,9 \%)$ oraz łódzkie $(25,3 \%)$, 
natomiast najniższe: podkarpackie (18,5\%), śląskie (18,6\%), małopolskie $(19,4 \%)$ oraz dolnośląskie (19,9\%) (ryc.1). Zdaniem K. Czapiewskiego i B. Głębockiego (2010, s. 61) wiek właściciela gospodarstwa rolnego jest silnie powiązany z wielkością gospodarstwa rolnego - mniejsze gospodarstwa prowadzone są zwykle przez osoby starsze, natomiast w większych, powyżej 20 ha, połowa właścicieli ma mniej niż 45 lat.

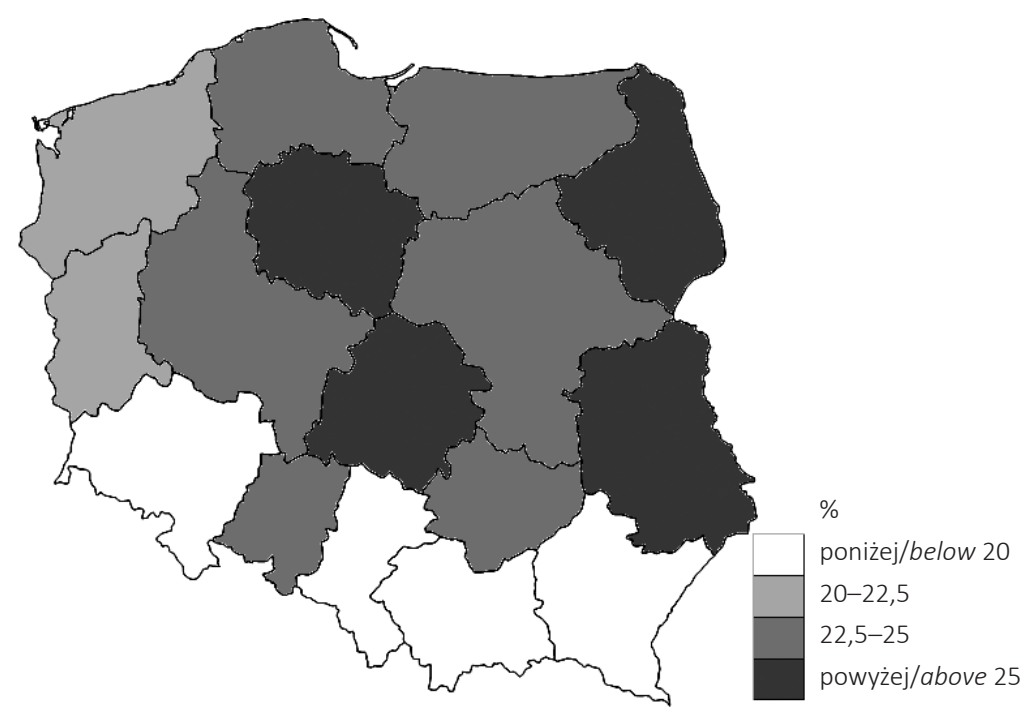

Ryc. 1. Udział gospodarstw rolnych z właścicielami do 40 roku życia w województwach Polski w 2010 r. Share of agricultural holdings (farms) with owners up to 40 years of age in the voivodships of Poland in 2010 Źródło/Source: opracowanie własne na podstawie/own elaboration based upon: Charakterystyka gospodarstw rolnych... 2014, s. 438.

Kolejnym problemem jest poziom wykształcenia użytkowników gospodarstw rolnych. Mimo iż na wsi ciągle ulega on podwyższeniu, to różnice w poziomie wykształcenia mieszkańców miast i wsi wciąż pozostają duże. Jak podkreśla B. Klepacki (2007, s. 231-235) niski poziom wykształcenia posiadaczy gospodarstw rolnych może wpływać na obniżenie tempa modernizacji rolnictwa oraz zmniejszenie możliwości rozwijania pozarolniczej działalności gospodarczej na obszarach wiejskich jako alternatywnego miejsca zatrudnienia dla występujących nadwyżek siły roboczej.

Średnia wartość wskaźnika udziału gospodarstw rolnych prowadzonych przez rolników z co najmniej średnim wykształceniem dla kraju kształtuje się na poziomie 61,7\%. W układzie województw wartości charakteryzują się znacznym zróżnicowaniem. Najwyższy udział notują województwa: zachodniopomorskie (75,4\%), lubuskie (71,3\%), dolnośląskie (70,3\%) oraz kujawsko-pomorskie (65,6\%). Natomiast najniższym cechują się województwa: małopolskie (46,9\%), podkarpackie $(53,2 \%)$, łódzkie $(55,8 \%)$ oraz świętokrzyskie (55,8\%) (ryc. 2).

Polska (w porównaniu z krajami Unii Europejskiej) charakteryzuje się jednym z najwyższych udziałów ludności, która jest związana z rolnictwem. Sytuacja ta kształtuje się podobnie, porównując poziom nakładów pracy w rolnictwie w AWU na 100 ha użytków rolnych. AWU (z ang. Annual Work Unit) według metodologii Eurostatu oznacza umowne roczne jednostki pracy, które wyrażają ekwiwalent pełnego etatu wynoszącego w sektorze 
rolnym 1800 godzin rocznie (225 dni pracujących po 8 godzin dziennie). Według K. Czapiewskiego (2010, s. 39) za główną przyczynę takiego stanu należy uznać niekorzystną strukturę agrarną w większości województw Polski oraz nadwyżkę osób zatrudnionych w rolnictwie (tzw. bezrobocie ukryte).

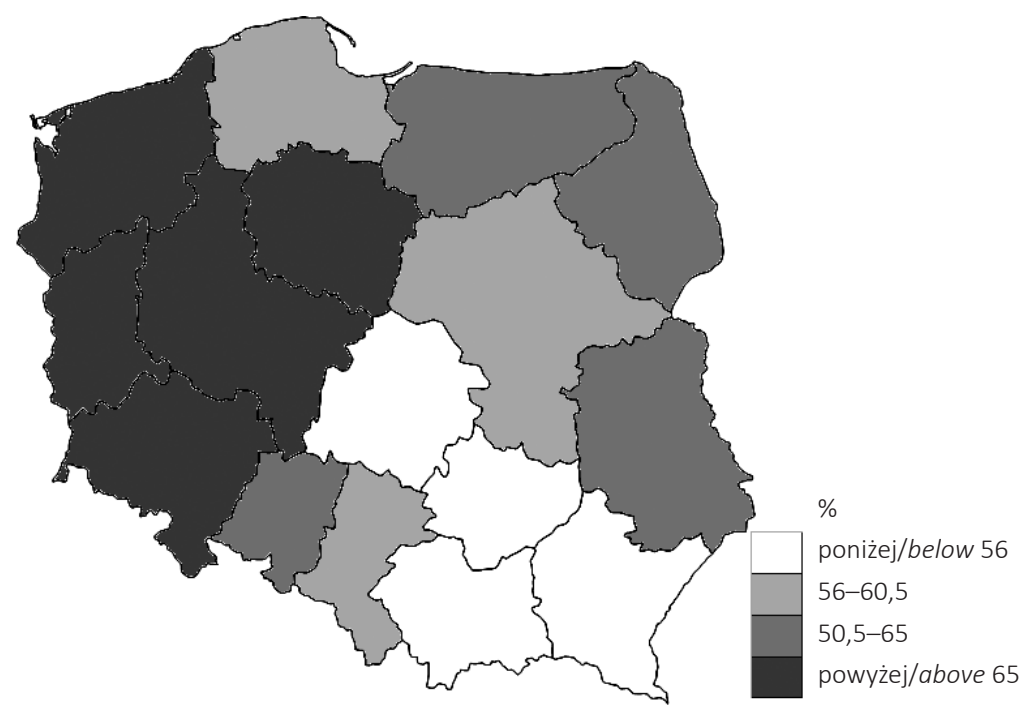

Ryc. 2. Udział gospodarstw rolnych prowadzonych przez rolników z co najmniej średnim wykształceniem w województwach Polski w 2013 r.

Share of agricultural holdings (farms) operated by farmers with at least secondary education in the voivodships of Poland in 2013

Źródło/Source: opracowanie własne na podstawie/own elaboration based upon: Charakterystyka gospodarstw rolnych... 2014, s. 408-409.

Średnia wartość wskaźnika rolnej siły roboczej mierzona w AWU na 100 ha użytków rolnych dla kraju wynosi 12,7 . W układzie województw również charakteryzuje się znacznym zróżnicowaniem. Najniższe wartości notowane są w województwach: zachodniopomorskim (3,9 AWU/100 ha UR), lubuskim $(5,7)$, warmińsko-mazurskim $(5,9)$ oraz pomorskim (6,9). Najwyższe wartości występują natomiast w województwach: małopolskim $(27,9)$, świętokrzyskim $(23,1)$, podkarpackim $(22,0)$ oraz lubelskim $(17,5)$ (ryc. 3). Wysokie wartości omawianego wskaźnika mogą świadczyć o braku alternatyw dla produkcji rolnej w regionie - potencjał ekonomiczny poszczególnych regionów jest zbyt mały, by móc kreować pozarolnicze miejsca pracy.

Zdaniem S. Krasowicza oraz M. Matyki (2012, s. 71) na warunki produkcji rolnej ma wpływ również struktura obszarowa gospodarstw rolnych. Gospodarstwa o małej powierzchni mogą ograniczać możliwość produkcji energii odnawialnej z biomasy rolniczej, ponieważ, jak podkreślają J. Knop i in. (2006, s. 112-116), dysponują one niewystarczającymi środkami dla opłacalnej produkcji (np. biogazu, uprawy roślin energetycznych). Produkcja energii odnawialnej z biomasy rolniczej jest opłacalna, gdy odbywa się na odpowiednio dużej powierzchni (lub przy znacznej liczbie pogłowia zwierząt), mogąc zaspokoić potrzeby lokalnych instalacji. 


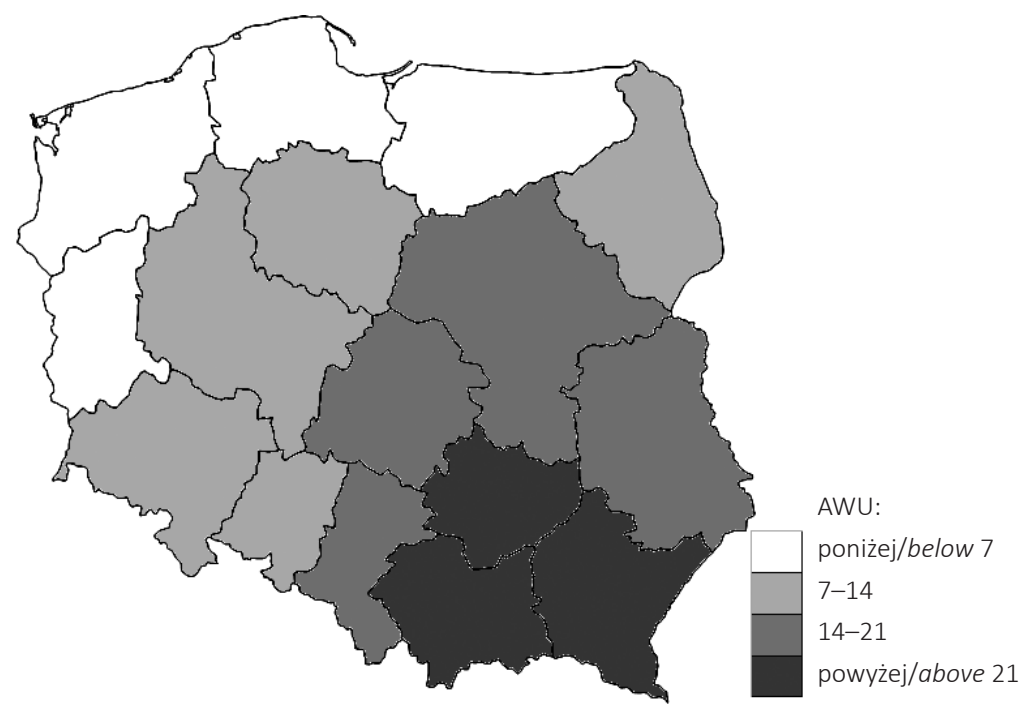

Ryc. 3. Rolna siła robocza w AWU na 100 ha użytków rolnych w województwach Polski w 2013 r. Źródło: Opracowanie własne na podstawie: Rocznik statystyczny rolnictwa 2014, s.152.

Farm labour force in AWU per 100 hectares of agricultural land in the voivodships of Poland in 2013 Source: Own elaboration based upon: Statistical yearbook of agriculture 2014, s. 152.

Udział gospodarstw wielkopowierzchniowych (100 ha i więcej) w ogólnej liczbie gospodarstw rolnych w układzie regionalnym waha się od 0,1\% do 5,4\% (ryc. 4). Średnia wartość tego wskaźnika kształtuje się na poziomie 1,4\%. Najwyższe udziały notują województwa: zachodniopomorskie (5,4\%), lubuskie (3,4\%), warmińsko-mazurskie (3\%) oraz dolnośląskie (2,2\%). Znacznie niższe odnotowano w województwach: świętokrzyskim $(0,1 \%)$, małopolskim $(0,1 \%)$, łódzkim $(0,2 \%)$, lubelskim $(0,3 \%)$, podkarpackim $(0,3 \%)$ oraz mazowieckim (0,3\%). Niskie wartości tego wskaźnika mają związek z sytuacją polskiego rolnictwa cechującego się niekorzystną strukturą wielkościową gospodarstw rolnych oraz rozdrobnioną strukturą gruntów (Czapiewski i Głębocki 2010, s. 61). Według informacji Agencji Restrukturyzacji i Modernizacji Rolnictwa w 2013 r. średnia wielkość powierzchni gruntów rolnych w gospodarstwie rolnym Polski wynosiła 10,4 ha. Gospodarstwa o najmniejszej powierzchni występują w południowo-wschodniej części kraju (woj. małopolskie - 3,9 ha) i stopniowo zwiększają się w kierunku północnym oraz północno-zachodnim (woj. zachodniopomorskie - 30,2 ha).

Uwzględniając poziom nawożenia mineralnego oraz zużycie chemicznych środków ochrony roślin, Polska należy do krajów, w których procesy te nie wywierają negatywnego wpływu ani na środowisko, ani na jakość wytworzonych produktów. Z uwagi na niewielkie (miejscowe) zanieczyszczenie gleb metalami ciężkimi w kraju występują również korzystne warunki dla produkcji zdrowej (ekologicznej) oraz bezpiecznej żywności. Jednak, jak słusznie zauważają J. Igras oraz W. Lipiński (2006, s. 71-80), niski poziom nawożenia (mineralnego i organicznego) przy występującym w Polsce wysokim udziale gleb o niskiej i bardzo niskiej zasobności w składniki pokarmowe (kształtującym się na poziomie 40-50\%) może przyczynić się do degradacji potencjału produkcyjnego gleb, co w konsekwencji wpływa na wielkość i jakość plonów (również na mniejsze możliwości wykorzystania pozostałości na cele energetyczne). 


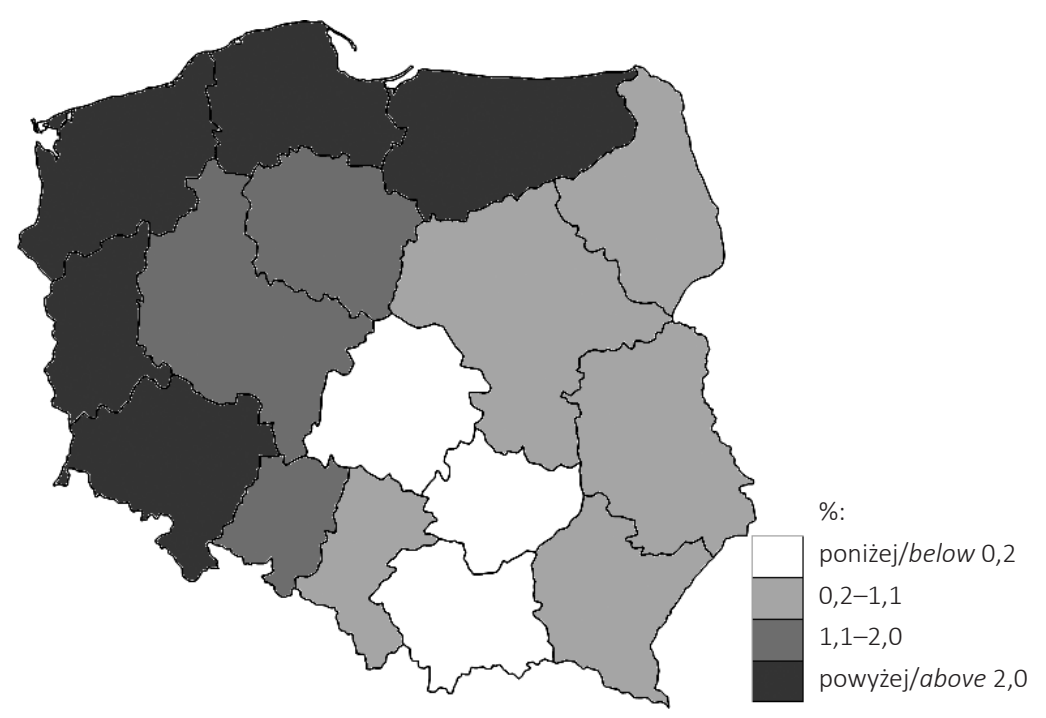

Ryc. 4. Udział gospodarstw wielkopowierzchniowych (100 ha i więcej) w ogólnej liczbie gospodarstw w 2013 r. Źródło: opracowanie własne na podstawie Banku Danych Lokalnych.

Share of agricultural holdings with the area over 100 hectares in all agricultural holdings in 2013

Source: own elaboration based upon Local Data Bank.

Zróżnicowanie zużycia nawozów mineralnych na 1 ha użytków rolnych w Polsce waha się od 68,2 do 223,5 kg na 1 ha (ryc. 5). Średnia wartość dla Polski kształtuje się na poziomie 135,5 kg na 1 ha użytków rolnych. Najwięcej nawozów mineralnych zużywa się w województwach: opolskim (223,5 kg/ha), lubuskim (188,5 kg/ha), kujawsko-pomorskim (174,3 kg/ha) oraz łódzkim (166,7 kg/ha), czyli na obszarach o stosunkowo wysokim poziomie rolnictwa. Natomiast najmniej stosuje się ich w regionach o słabych warunkach naturalnych, tj. w województwach: małopolskim (68,2 kg/ha), podkarpackim (74,9 kg/ha), mazowieckim (92,3 kg/ha) oraz podlaskim $(97,6 \mathrm{~kg} / \mathrm{ha})$.

Liczba ciągników na 100 ha użytków rolnych traktowana jest zwykle jako miara wyposażenia rolnictwa w czynniki techniczne. Zdaniem K. Kucińskiego (2007, s. 281) poza poziomem rozwoju rolnictwa i gospodarki na wysokość tego wskaźnika wpływają również charakter użytków rolnych oraz typ struktury agrarnej. Wyższe wartości zwykle obserwuje się w przypadku małej powierzchni użytków rolnych oraz w małych gospodarstwach, natomiast niższe w gospodarstwach o dużej powierzchni. Fakt ten potwierdza analiza poszczególnych województw Polski.

Średnio w Polsce przypada 9 ciągników na 100 ha użytków rolnych, ale wartość ta jest silnie zróżnicowana przestrzennie. Najwięcej występuje w województwach: małopolskim - 16 szt./100 ha UR, świętokrzyskim - 15, podkarpackim - 14 oraz łódzkim - 13. Natomiast najmniej w: zachodniopomorskim - 3, lubuskim - 4, warmińsko-mazurskim - 5 oraz pomorskim -6 .

W wyniku przeprowadzonej analizy wskaźnikowej województwa podzielono na trzy klasy o różnym poziomie uwarunkowań społeczno-ekonomicznych dla produkcji energii odnawialnej z biomasy rolniczej (tab. 1, ryc. 7). 


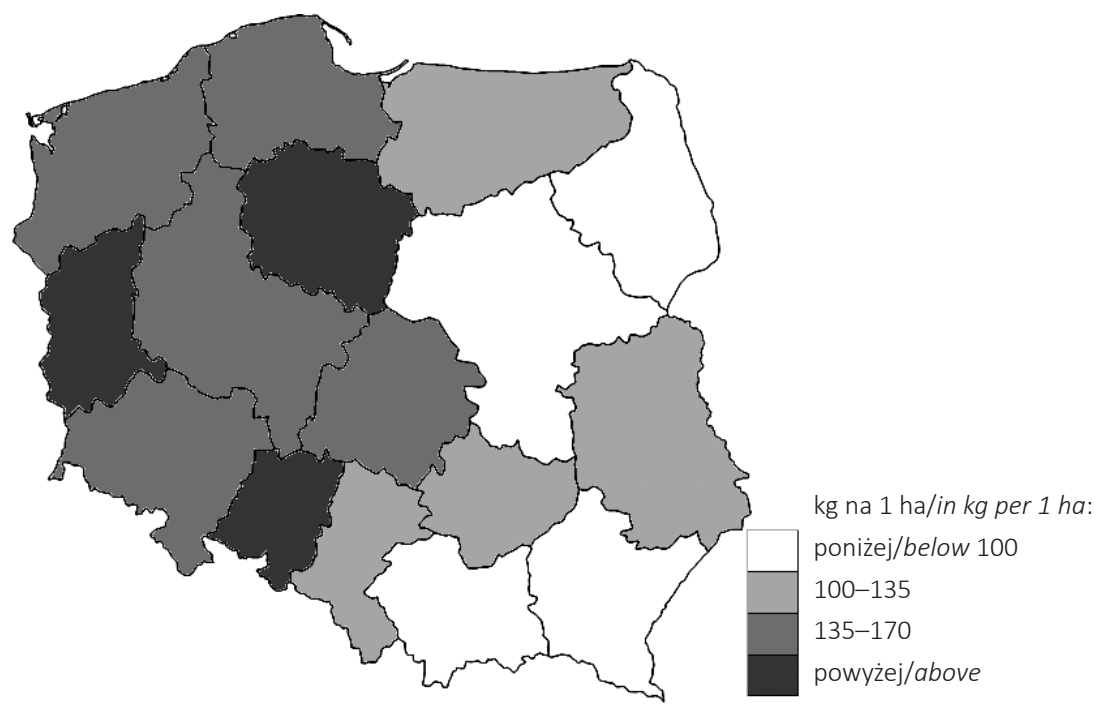

Ryc. 5. Zużycie nawozów mineralnych na 1 ha użytków rolnych w województwach Polski w 2013 r. Źródło: opracowanie własne na podstawie Banku Danych Lokalnych.

Usage of mineral fertilizers per 1 ha of agricultural land in the voivodships of Poland in 2013 Source: own elaboration based upon Local Data Bank.

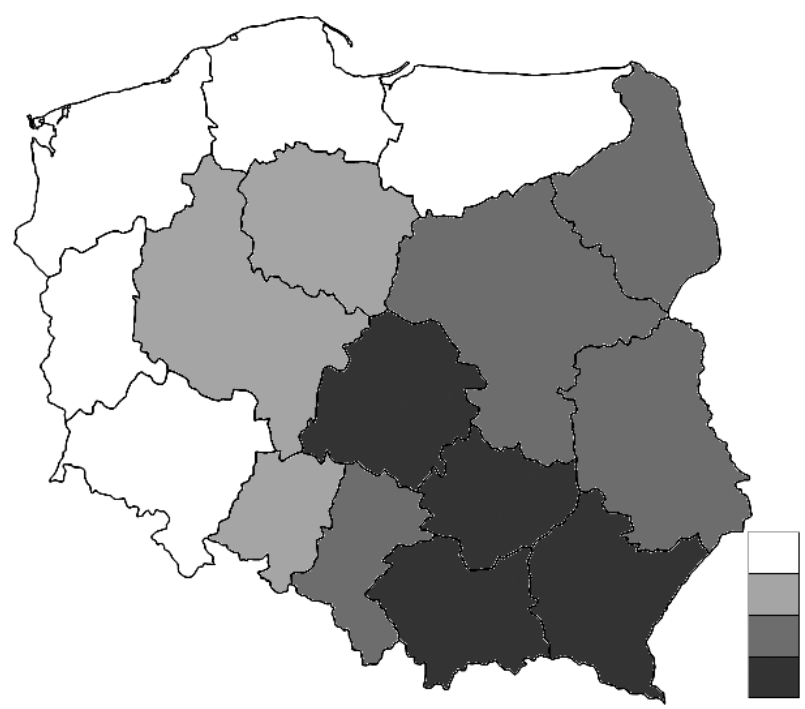

Na 100 ha UR/ per 100 ha of agricultural land poniżej/below 6,5 $6,5-9,5$

$9,5-12,5$

powyżej/above 12,5

Ryc. 6. Liczba ciągników przypadająca ha 100 ha użytków rolnych w 2013 r. Źródło: opracowanie własne na podstawie Banku Danych Lokalnych. Number of tractors per 100 hectares of agricultural land in 2013 Source: own elaboration based upon Local Data Bank. 
Tabela 1. Wskaźniki zróżnicowania uwarunkowań społeczno-ekonmicznych dla produkcji energii odnawialnej z biomasy rolniczej w województwach Polski.

\begin{tabular}{|l|r|r|r|r|}
\hline \multicolumn{1}{|c|}{ Wyszczególnienie } & \multicolumn{1}{|c|}{$\begin{array}{c}\text { Klasa } \\
\text { I }\end{array}$} & \multicolumn{1}{|c|}{$\begin{array}{c}\text { Klasa } \\
\text { II }\end{array}$} & \multicolumn{1}{|c|}{$\begin{array}{c}\text { Klasa } \\
\text { III }\end{array}$} & Ogółem \\
\hline Udział gospodarstw z właścicielem do 40 roku życia & 23,1 & 24,2 & 19,8 & 22,8 \\
Rolna siła robocza w AWU na 100 ha użytków rolnych & 7,3 & 11,4 & 21,9 & 12,7 \\
Udział gospodarstw z kierującym posiadającym minimum średnie wykształcenie & 68,1 & 61,8 & 53,6 & 61,7 \\
Udział gospodarstw wielkopowierzchniowych w ogólnej liczbie gospodarstw & 2,6 & 1,2 & 0,2 & 1,4 \\
Zużycie nawozów mineralnych na 1 ha użytków rolnych & 174,8 & 130,3 & 95,6 & 135,5 \\
Liczba ciągników przypadająca ha 100 ha użytków rolnych & 6,2 & 8,9 & 13,8 & 9,3 \\
Liczba jednostek w klasie & 5,0 & 7,0 & 4,0 & 16,0 \\
Średnia wartość miernika syntetycznego w klasie & 0,6 & 0,5 & 0,3 & 0,5 \\
\hline
\end{tabular}

Źródło: opracowanie własne.

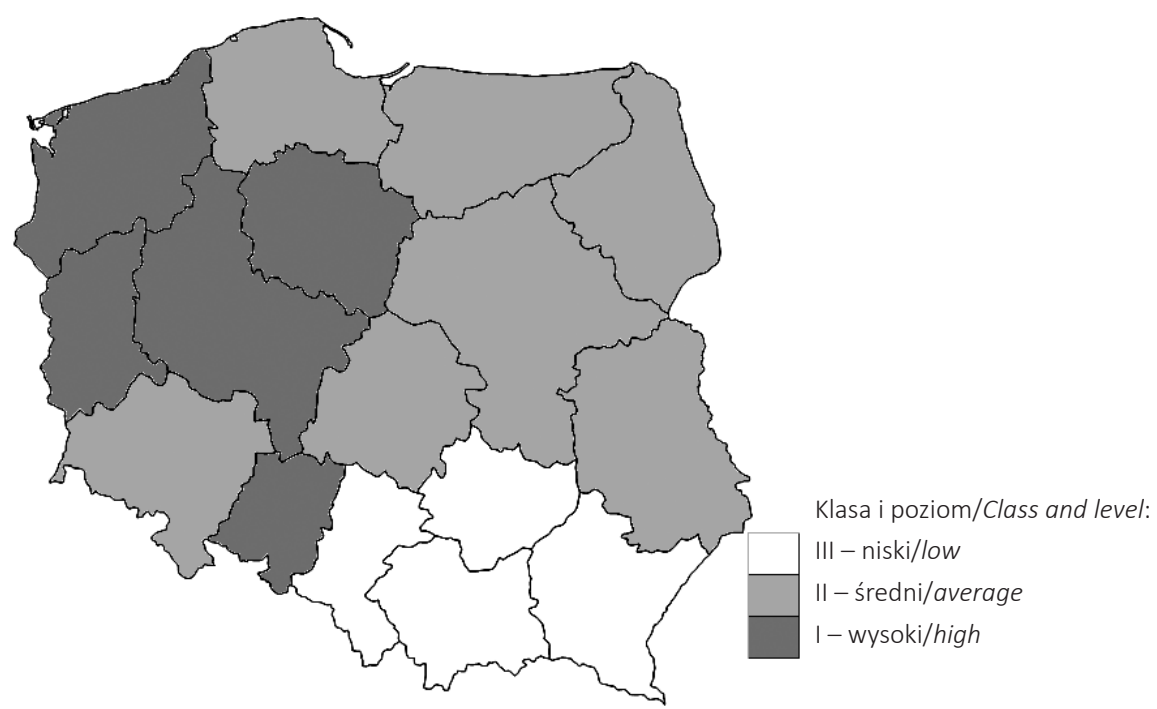

Ryc. 7. Poziom uwarunkowań społeczno-ekonomicznych dla produkcji energii odnawialnej z biomasy rolniczej w województwach Polski Źródło: opracowanie własne.

Level of socio-economic determinants for renewable energy production using agricultural biomass in the voivodships of Poland

Source: Own elaboration.

Pierwsza klasa - charakteryzująca się najwyższym poziomem uwarunkowań społeczno-ekonomicznych (wartość wskaźnika syntetycznego na poziomie powyżej 0,55), obejmuje pięć województw: lubuskie, wielkopolskie, zachodniopomorskie, opolskie oraz kujawsko-pomorskie. Jednostki te cechują się najwyższym spośród pozostałych grup udziałem gospodarstw wielkopoowierzchniowych (2,6\%), gospodarstw z kierującym posiadającym minimum wykształcenie średnie $(68,1 \%)$ oraz zużyciem nawozów mineralnych 174,8 kg/ha UR. Natomiast najniższe wartości, porównując do pozostałych dwóch klas, odnotowano w zakresie rolnej siły roboczej - 7,3 AWU/100 ha UR oraz 6,2 ciągników przypadających na 100 ha UR. 
Druga klasa, charakteryzująca się przeciętnym poziomem uwarunkowań (wartość wskaźnika syntetycznegogo na poziomie 0,41-0,55), okazała się najbardziej liczna i zgromadziła 7 województw: łódzkie, mazowieckie, lubelskie, podlaskie, dolnośląskie, pomorskie oraz warmińsko-mazurskie. Poszczególne wartości wskaźników w tej grupie okazały się bardzo zbliżone do wartości średniej dla całego kraju.

Klasa trzecia, charakteryzująca się niskim poziomem uwarunkowań społeczno-ekonomicznych (średnia wartość wskaźnika syntetycznego poniżej 0,41), obejmuje tylko cztery województwa: małopolskie, śląskie, podkarpackie oraz świętokrzyskie. Wartości poszczególnych wskaźników w większości przypadków znacznie odbiegają od średniej dla regionu. Regiony tej grupy charakteryzują się niższym od średniej krajowej udziałem gospodarstw z właścicielami do 40 roku życia - 19,8\% (średnia krajowa 22,8\%) oraz niskim udziałem kierujących z minimum średnim wykształceniem - 53,6\% (średnia krajowa 61,7\%). W klasie tej występuje niski udział gospodarstw wielkoobszarowych $(0,2 \%$, przy średniej krajowej 1,4\%) oraz niskie zużycie nawozów mineralnych (95,6 kg/ha UR przy średniej krajowej 135,5 kg/ha UR). Ponadto w grupie tej występuje najwyższa w porównaniu z resztą klas liczba ciągników oraz nakładów pracy wyrażonych w AWU przypadająca na 100 ha użytków rolnych.

\section{Podsumowanie}

Możliwości wykorzystania biomasy rolniczej na cele energetyczne w znacznym stopniu zależą od sposobu zorganizowania produkcji rolnej. Z przeprowadzonej analizy wynika, iż regiony Polski charakteryzują się znacznym zróżnicowaniem pod względem uwarunkowań społeczno-ekonomicznych dla rozwoju produkcji energii odnawialnej z biomasy rolniczej.

Najkorzystniejsze warunki występują w północno-zachodniej części Polski. Obszar ten charakteryzują się większą powierzchnią gospodarstw rolnych, wyższym poziomem wykształcenia właścicieli gospodarstw rolnych oraz niższymi nakładami pracy na 100 ha UR. Ponadto występuje tam wyższe zużycie nawozów mineralnych na 1 ha UR, co wpływa korzystnie na potencjał produkcyjny gleb. Natomiast odwrotnie sytuacja kształtuje się w województwach południowej części Polski, które cechuje zdecydowanie mniejsza średnia powierzchnia użytków rolnych w gospodarstwach. Właśnie z uwagi na rozdrobnienie agrarne występują tu wysokie nakłady pracy na 100 ha UR. Ponadto właściciele gospodarstw rolnych charakteryzują się niższymi kwalifikacjami zawodowymi oraz niższym udziałem rolników do 40 roku życia, co może wpływać na tempo zmian zachodzących w rolnictwie na tych obszarach.

Zdaniem S. Krasowicza i M. Matyki (2012, s. 75) występujące w Polsce rezerwy siły roboczej oraz niewielkie zanieczyszczenie środowiska stwarzają możliwość różnorodnej produkcji - zgodnie z systemem przyjaznym dla środowiska, w tym również biomasy na cele energetyczne. Może to stanowić czynnik, który wzmacnia pozycję Polski w walce konkurencyjnej. Jednak, aby uzyskać z tego tytułu wymierne korzyści, należy w większym stopniu wykorzystać istniejący potencjał rolnictwa regionów. Obecnie za jeden z głównych czynników wpływających na efektywność rolnictwa (lepsze efekty produkcyjne, lepsze wykorzystanie zasobów ziemi, pracy oraz środków obrotowych), a w związku tym również na jego konkurencyjność (gospodarstw rolnych) uznaje się poziom wykształcenia kierują- 
cych gospodarstwami. W regionach o wysokim udziale gospodarzy z niskimi kwalifikacjami zawodowymi przeprowadzanie modernizacji, dostosowanie się do wyższych wymogów jakości produkcji, jak również wykazywanie inicjatywy i pozyskiwanie środków zewnętrznych może być utrudnione.

\section{Literatura}

Agencja Restrukturyzacji i Modernizacji Rolnictwa, http://www.arimr.gov.pl/dla-beneficjenta/srednia-powierzchnia-gospodarstwa.html, dostęp: 2.04. 2015.

Bank Danych Lokalnych GUS, http://stat.gov.pl/bdl/app/strona.html? p_name=indeks, dostęp: 1.04-15.04.2015.

Charakterystyka gospodarstw rolnych w 2013 roku, 2014, Informacje i Opracowania Statystyczne, Warszawa.

Czapiewski K., Głębocki B., 2010, Struktura agrarna, [w:] J. Bański (red.), Atlas Rolnictwa Polski, IGiPZ PAN, Warszawa, s. 55-64.

Czapiewski K., 2010, Zatrudnienie w rolnictwie, [w:] J. Bański (red.), Atlas Rolnictwa Polski, IGiPZ PAN, Warszawa, s. 39-42.

Dyrektywa Parlamentu Europejskiego i Rady 2009/28/WE z dnia 23 kwietnia 2009 r. w sprawie promowania stosowania energii ze źródeł odnawialnych zmieniająca i w następstwie uchylająca dyrektywy 2001/77/WE oraz 2003/30/WE.

Igras J., Lipiński W., 2006, Regionalne zróżnicowanie stanu agrotechnicznego gleb w Polsce [w:] Regionalne zróżnicowanie produkcji rolniczej w Polsce, Raporty PIB, IUNG, Puławy, s. 71-80.

Klepacki B., 2007, Niematerialne czynniki rozwoju rolnictwa polskiego, Roczniki Naukowe SERiA, 9 (1), s. 231-235.

Knop J., Kucharska M., Szkurłat E., 2006, Geografia społeczno-ekonomiczna, Wydawnictwo Szkolne PWN, Warszawa.

Krasowicz S., Matyka M., 2012, Uwarunkowania ekonomiczne i społeczne, [w:] B. Kołodziej, M. Matyka (red.), Odnawialne źródła energii. Rolnicze surowce energetyczne, PWRiL, Poznań, s. 65-75.

Kuciński K., 2007, Geografia ekonomiczna, Kompendium w zarysie i w zadaniach, Difin, Warszawa.

Kuś J., Madej A., Kopiński J., 2006, Bilans słomy w ujęciu regionalnym, Regionalne Zróżnicowanie produkcji rolniczej w Polsce, 3, IUNiG, PIB, Puławy, s. 211.

Parysek J.J., Wojtasiewicz L., 1979, Metody analizy regionalnej i metody planowania regionalnego, Studia, t. LXIX, Polskie Wydawnictwo Naukowe, Warszawa.

Poczta W., 2010, Przemiany w rolnictwie, [w:] J. Wilkin, I. Nurzyńska (red.), Raport o stanie wsi. Polska wieś 2010, Wyd. Scholar, Warszawa, s. 9-43.

Poczta W. (red)., 2013, Gospodarstwa rolne w Polsce na tle gospodarstw Unii Europejskiej - wpływ WPR, Powszechny Spis Rolny 2010, GUS, Warszawa.

Rocznik statystyczny rolnictwa, 2014, GUS, Warszawa.

Wysocki F., Lira J. 2003, Statystyka opisowa, Wyd. AR w Poznaniu, Poznań.

Zegar J.S., 2012, Wspótczesne wyzwania rolnictwa, Wydawnictwo Naukowe PWN, Warszawa. 


\section{Summary}

The main aim of this research was to identify the level of socio-economic determinants for renewable energy production from agricultural biomass in Poland. Examining these determinants was conducted at voivodships level (rural areas) and was based upon data from the Local Data Bank. The voivodships determinants level was defined using synthetic indicator. For this analysis the following indicators were applied: share of agricultural holdings (farms) with owners up to 40 years of age, farm labor force in AWU per 100 hectares of agricultural land, share of agricultural holdings (farms) operated by farmers with at least secondary education, share of agricultural holdings with 100 hectares and more area in the total number of farms, usage of mineral fertilizers per 1 ha of agricultural land and tractors per 100 hectares of agricultural land. As a result of implementing such synthetic indicator the examined regions were divided into three groups. 